After 41 years and 8 months the beetle was in perfect state of preservation; legs, feelers and all appendages intact. One week after removal the external canal appeared normal and the hearing is nearly normal.

F. B. Marshall, M.D.

\section{Plaster-of-Paris Bandages.}

'Toledo, Orio, May 8, 1903.

To the Editor:-It is not generally known that the late Dr. Hezekiah P. Mead of Morrisville, Madison County, N. Y., who died last year, was the first to discover the practicability of applying the plaster-of-paris bandage to the treatment of fractures and other displacements in which it is so universally used by the profession throughout the land. This was early in the year 1860.

With an utter lack of any thirst for notoriety, and content with his mere contribution to the profession and to the good of bumanity, he gracefully allowed the name of another skilled and more prominent surgeon of the time to be credited with this valuable discovery.

Through intimate association and personal knowledge of the facts at the period named, I have felt it incumbent on me to call attention to the above fact, in justice to a man of consummate skill and the highest citizenship. In a personal reminiscence which I caused to be published in the rolcdo Blade in 1901, I gave in some detail the circumstanees which first led to the adoption of this new use of a common and well-known article, and which I believe I am able to substantiate if desired.

N. B. BACON.

\section{Failure of the Eddyites in Arkansas.}

Winfield, ARK., May 12, 1903.

To the Editor:-I see in Thw Journad, May 9, that the Eddyites failed to receive a charter in Philadelphia. At the past session of the Arkansas legislature these people got a bill through the senate to exempt them from Section 13 of the recent medical act of the state, but in the house we managed to put an amendment on the bill "providing that they receive no pay for their practice." The senate never concurred in the amendment, so they are out here.

Cheves Bevill.

\section{Triplets.}

Hope, Ark., May 19, 1903.

To the Editor:-May 14 I delivered Mrs. M. of triplets, two girls, one boy. The weights of the two girls were $51 / 2$ and 6 pounds and of the boy $61 \% 2$ pounds. They are all hale and hearty and at this time are doing nicely. Mrs. M., who is the mother of four other children, is also doing nicely. She had the easiest time of any of her confinements.

\section{J. H. WEAVER.}

\section{Queries and Minor Notes.}

Anonimots Communicatrons will not be noticed. Queries for this column must be accompanied by the writer's name and address, but the request of the writer not to publish his name will be faithfully observed.

\section{DO NEGROES RECOVER FROM PHTHISIS?}

Albequerque, N. M., May 13, 1903.

To the Editor:-I desire to learn through the columns of THE JoURNal, from one or more physicians residing in southern states and who have had any considerable number of cases of pulmonary tuberculosis among the African race, if they know a recovery among negroes suffering from this disease. I desire the information for statistical use and will consider it a great kindness from anyone who can give me such aid, either by personal communication or through The Journal,

Francis Crosson.

\section{SALOL COATED IPECAC PILIS.}

Newaray Grove, Neb., May 15, 1903.

To the Editor:-Will you please inform me where I can get ipecac pills that are coated with salol? D. B. MCMAHON, M.D.

Axs.-We are unable to learn of any such ready-made pills. Any of the large pharmaceutical houses, however, will prepare these for you, or perhaps a druggist in your own city will be able to do the same satisfactorily.

\section{PINK REACTION IN URINE.}

Philadeliphis, May 18, 1903.

To the Editor:-With reference to the pink coloration of urine noted by Dr. Minter in The Jovinal, May 16, p. 1386, on addition of nitric acid: I have observed such a reaction in a case in which also tubercle bacilli were found in the urine, and the same observation has been made, I believe, by Dr. Joseph Walsh of this city. Augustus A. Esharer.

\section{PHOSPHORUS ELIMINATION IN TABES.}

Matagorda; Texas, May 6, 1903.

To the Editor:-Has it been observed that there is an increased elimination of phosphorus through the urine in tabes dorsalis? And, if so, has the administration of phosphoric acid been recom mended for treatment of this disease? S. A. F.

\section{Book Notices.}

Thi Prevention of Disfase. Translated from the German with an Introduction by f. Timbrell Bulstrode, M.A.. M.D.. D.P.H. In Two Volumes. Cloth. Pp. 1063. Net Price $\$ 3.7$

This is a translation of a well-known German work, a composite production by numerous teachers. The names of the authors give, in themselves, a fairly good ictea of the merits of the work, including as they do some of the most eminent specialists and internists of the German Empire. There are, of course, in a work like this some divergences of opinion and in one particular it seems peculiar that a book coming from the publishing house of Funk \& Wagnalls should contain arguments advising the moderate use of alcohol and even occasionally the taking of a little more than usual on festive occasions, as suggested in Dr. Einhorn's article on the "Prevention of Diseases of the Digestive Organs." In another article, that of Fuchs on the "Prevention of Mental Disease," total abstinence seems to be advocated, at least on the part of the physician. The two volumes as a whole, however, are a valuable addition to the hygienic medical literature in our language.

Therapeutics of INFANCY AND CHILDHOOD. By A. Jacobi, M.D. I.L.D. Third Edition. Cloth. Pp. 559. Price, \$3.50. Philadeiphia and London: J. B. Lippincott Co. 1903.

As the author says in his introduction, while many additions have been made to the book, there have been no actual changes in its general contour. It is the revision of a well-known work which has already received its share of favor with the profession. The author's views in regard to the at present much discussed question of infant feeding are stated by him in the beginning, that there will be no unanimity on the question as long as infants insist on being individuals, having their own special constitutional idiosyncrasies. The author acknowledges his indebtedness to the contributors to the Festschrift published in his honor between two and three years ago, than which he says he knows of no collection of an equal number of monographs on scientific and practical subjects of equal value connected with pediatrics.

Book on the Physician fIImSElf and Things that Concern His Reputation and Success, by $D$. W. Cathell, M.D. The 'Twentieth Century Edition, Being the Eleventh Edition Revised and Enlarged by the Author and IHis Son, William T. Cathell, A.M., M.D. Cloth 1902 .

The appearance of the eleventh edition of a work ought to be sufficient evidence of its popularity. This book has been before the medical public for many years. There is no other exactly like it in its combination of worldly wisdom and ethical advice. Numerous quotations interpolated in the book remind one of the Jatin quotations in old Burton's "Anatomy of Melancholia," but they are so funnily chopped up and sawed off in some cases that the impression is somewhat different. We do not consider them a valuable addition.

Physical Chenistry for Physicians and Biologists. By Dr. Ernest Cohen, Professor of General and Inorganic Chemistry in the By urtin $H$. Fischer, By Martin H. Fischer, M.D., Instructor in Fhysiology in the University of Cain

Nowadays when the ions, electrolytes, ete., are beginning to play such an important part in the discussions of therapeutics and physiology, a work like this translation of Prof. Cohen's should be welcomed. As a preliminary note to the American 